\title{
KEEFEKTIFAN PELAKSANAAN PRINSIP PENDIDIKAN SISTEM GANDA SMKN 1 PANGKALAN KERINCI DAN SMKN 1 UKUI KABUPATEN PELALAWAN
}

\author{
Rika Ariani, Achmad Dardiri \\ Dinas Pendidikan Kabupaten Pelalawan, Universitas Negeri Yogyakarta \\ ikhamanis@gmail.com, achmaddardiri@yahoo.com
}

\begin{abstract}
Abstrak
Penelitian ini bertujuan untuk mengetahui keefektifan pelaksanaan prinsip Pendidikan Sistem Ganda (PSG) di SMKN 1 Pangkalan Kerinci dan SMKN 1 Ukui ditinjau dari sisi (1) konteks, (2) input, (3) proses dan (4) produk/hasil. Metode penelitian yang digunakan adalah studi evaluasi dengan analisis deskriptif kuantitatif, dengan menggunakan metode CIPP (Context, Input, Process, Product) dari Stufflebeam. Subyek penelitian adalah kepala sekolah, wakil kepala sekolah urusan Dunia Usaha dan Industri (Humas), wakil kepala sekolah urusan kurikulum, ketua jurusan masing-masing prodi, guru, dan 123 siswa yang telah melaksanakan PSG untuk jurusanTeknik Komputer Jaringan, Teknik Sepeda Motor, dan Teknik Kendaraan Bermotor. Pengumpulan data dilakukan dengan wawancara, observasi, dan kuesioner. Hasil penelitian ini menunjukan dari sisi (1) konteks: organisasi pelaksana/manajemen program pelaksanaan PSG sudah terstruktur, relevansi program PSG sudah cukup relevan dengan skill dan jurusan siswa, dan secara keseluruhan variable konteks ini sangat efektif, (2) input: pengelolaan peserta pelaksana PSG, tenaga kependidikan, kurikulum, sarana dan prasarana PSG, dan pembiayaan PSG telah terkelola dengan baik, dan variabel input sudah efektif, (3) proses: proses persiapan pelaksanaan PSG di sekolah sudah terorganisir dengan baik, namum proses pelaksanaan PSG oleh siswa pada Dunia Usaha dan Dunia Industri tidak terlaksana sepenuhnya seperti yang telah diprogramkan, dan pada umumnya variabel proses sudah efektif, (4) aspek hasil kemanfaatan pelaksanaan PSG telah meningkatkan rasa percaya diri siswa dalam menghadapi Ujian Nasional dan meningkatkan kemampuan siswa dibidangnya dan variabel produk sangat efektif.
\end{abstract}

\section{THE EFFECTIVENESS OF IMPLEMENTING DUAL EDUCATION SYSTEM PRINCIPLE AT SMKN 1 PANGKALAN KERINCI AND SMKN 1 UKUI, PELALAWAN}

\begin{abstract}
The objective of this research is to reveal the effectiveness of the implementation of the dual education system (PSG) principle at SMKN 1 Pangkalan Kerinci and SMKN 1 Ukui from the point of view of (1) context, (2) inputs, (3) process and (4) product/results. The research was evaluation research type, with descriptive quantitative approaches analysis data, employing CIPP method (Context, Input, Process, Product) from Stufflebeam. The research subjects were the school principals, the deputy principal of the Business and Industry affair (Public Relation), deputies principal of the curriculum, department head of each study program, teachers, and 123 students who have carried out PSG for the Department of Computer Engineering Network (TKJ), Motorcycles Engineering (TSM), and Motor Vehicle Engineering (TKR). Data were collected through interview, observation and questionnaires. The results of this research indicates that (1) in the terms of management organization context, the implementation of the program PSG has been structured; in term of relevancy, PSG program relevance was relevant enough with students' skill and department; and based on respondent's evaluation, in overall of the context variable, PSG very effective, (2) in the input variable, PSG executive management participants, staff, curriculum, facilities and infrastructure of PSG and PSG financing have been managed well. Based on respondent's evaluation, the input variable hasa sufficient effectiveness level, (3) in the processes variable, the preparation process of the PSG program in school has been well organized, but the process of implementation of the PSG program by the students at the Business and Industry World (DUDI)was not fully implemented, and in general the process variable has a sufficient level of effectiveness,(4) the product aspect, this program gave benefit to increase the confidence of students to the face the National Examination and improve the student's ability and the product variable has a sufficient level of very effective.
\end{abstract}




\section{Pendahuluan}

Pemerintah telah mempercepat perencanaan pelaksanaan Millenium Development Goals, yang semula dicanangkan tahun 2020 dipercepat menjadi 2015. Millenium Development Goals adalah era pasar bebas atau era globalisasi, sebagai era persaingan mutu atau kualitas. Dalam mempersiapkan diri menghadapi pasar bebas tersebut khususnya kerja sama perekonomian Negara-Negara Asia Tenggara melalui Komunitas Ekonomi ASEAN (KEA) yang akan mulai diberlakukan tahun 2015 akan menimbulkan persaingan ketat di segala bidang baik dalam bentuk barang jadi/komoditas maupun jasa. Hal ini berdampak pada peningkatkan daya saing baik mutu hasil produksi maupun jasa bagi Indonesia sebagai salah satu negara yang ada didalamnya. Peningkatan daya saing ini dimulai dari penyiapan Sumber Daya Manusia (SDM) berkualitas yang merupakan faktor keunggulan menghadapi persaingan dimaksud. Indonesia akan menjadi korban perdagangan bebas jika tidak bisa mengantisipasi persiapan SDM yang berkualitas di dalam pendidikan, keahlian dan keterampilan terutama bagi tenaga kerja. Oleh karena itu, Indonesia perlu menyiapkan SDM mulai dari tingkat menengah yang memiliki kemampuan yang sesuai dengan kebutuhan industri atau dunia usaha hingga tingkat atas yang memiliki kualitas pendidikan yang lebih matang. Keberhasilan pembangunan suatu bangsa diukur dari meningkatnya kwalitas sumber daya manusia. Sekolah Menengah Kejuruan (SMK) adalah salah satu jenjang pendidikan menengah dengan kekhususan mempersiapkan lulusannya untuk siap bekerja. Selain itu, SMK juga merupakan salah satu lembaga pendidikan yang mempunyai tujuan mempersiapkan peserta didik agar menjadi manusia produktif, mampu bekerja mandiri, mengisi lowongan pekerjaan yang ada di Dunia Usaha dan Dunia Industri (DU/DI) sebagai tenaga kerja tingkat menengah, sesuai dengan kompetensi dalam program studi keahlian pilihannya, membekali peserta didik agar mampu memilih karir, ulet dan gigih da- lam berkompetisi, beradaptasi di lingkungan kerja dan mengembangkan sikap dalam bidang keahlian yang diminatinya, membekali peserta didik dengan ilmu pengetahuan, teknologi, dan seni agar mampu mengembangkan diri dikemudian hari baik secara mandiri maupun melalui jenjang pendidikan yang lebih tinggi. Salah satu kebijakan Departemen Pendidikan dan Kebudayaan Republik Indonesia yang dikembangkan untuk meningkatkan relevansi SMK adalah menciptakan kerjasama antara dunia pendidikan dan industri yang dikenal dengan istilah link and macth, yaitu merupakan relevansi pendidikan dengan kebutuhan pembangunan umumnya dan kebutuhan dunia kerja, dunia usaha serta dunia industri khususnya. Beberapa prinsip yang akan dipakai sebagai strategi dalam kebijakan Link and Match diantaranya adalah model penyelenggaraan Pendidikan Sistem Ganda (PSG). Peraturan Pemerintah Nomor 29 tahun 1990 menyebutkan dalam Pasal 1 Ayat 3 bahwa "pendidikan menengah kejuruan adalah pendidikan pada jenjang pendidikan menengah yang mengutamakan pengembangan kemampuan siswa untuk melaksanakan jenis pekerjaan tertentu". Seperti yang dikemukakan oleh Oemar (2011, p.29) bahwa "sudah jelas kiranya bahwa pendidikan dan kurikulum harus mempersiapkan para siswa agar mereka mampu hidup sekarang dan dalam lingkungan masyarakat". Djojonegoro (1999, p.46) menjelaskan bahwa "pendidikan sistem ganda merupakan bentuk penyelenggaraan pendidikan dan pelatihan keahlian kejuruan yang secara sistematik dan sinkron antara program pendidikan di sekolah dengan program penguasaan keahlian yang diperoleh melalui kegiatan bekerja langsung di dunia kerja, terarah untuk mencapai suatu tingkat keahlian profesional tertentu". Sedangkan menurut Wena (1997, p.30) mengatakan bahwa "pemanfaatan dua lingkungan belajar di sekolah dan di luar sekolah dalam kegiatan proses pendidikan itulah yang disebut dengan program PSG". Pendidikan sistem ganda (dual system) adalah "memadukan pelatihan kejuruan paruh waktu dikom- 
binasikan dengan belajar paruh waktu" (The Educational System in Germany, 1999, p.1).

Dalam pelaksanaan PRAKERIN berdasarkan prinsip-prinsip PSG, banyak kendala dirasakan oleh kedua belah pihak, yaitu sekolah dan industri seperti yang diungkapkan oleh Direktorat Pendidikan Menengah Kejuruan (1996), disebutkan bahwa kendala yang dihadapi oleh sekolah antara lain: (1) keragaman geografis, (2) keragaman kesiapan dan tingkat kemajuan SMK, dan (3) keragaman program SMK yang belum seimbang dengan keragaman industri di sekitarnya. Selanjutnya, kendala yang dirasakan oleh industri antara lain: (1) belum dimiliki struktur jabatan dan keahlian yang mantap, terutama pada industri kecil, dan menengah, (2) belum ada perencanaan alokasi biaya untuk pengembangan pendidikan, (3) belum dimilikinya persepsi tentang keuntungan PSG bagi industri, dan (4) kurangnya kesadaran tentang peningkatan keefektifan, efisiensi, dan kualitas dalam pelaksanaan pelatihan di industri. Sedangkan menurut Zaenuri (2005, p.6), ada beberapa hambatan dalam pelaksanaan PSG SMK PGRI 01 Mejobo Kudus menurut pihak Institusi pasangan (DU/DI), yaitu antara lain: (1) kurangnya koordinasi, (2) kemampuan siswa relatif masih kurang, (3) rahasia perusahaan kepada siswa, (4) siswa kurang aktif, (5) adaptasi lingkungan kerja, (6) mengganggu pekerjaan instruktur, (7) siswa tidak disiplin, (8) fasilitas kerja yang kurang memadai, (9) waktu pelaksanaan PSG kurang, dan (10) siswa kurang kreatif. Dari temuantemuan di atas dapat disebutkan bahwa pelaksanaan PRAKERIN dengan prinsipprinsip PSG selama ini mengalami banyak mengalami kendala diantaranya kendalakendala industri, geografis, potensi teknologi, psikologis, akademis, dan manajerial.

Dari banyaknya kendala yang dihadapi dalam pelaksanaan PRAKERIN dengan prinsip-prinsip PSG tersebut peneliti tertarik untuk melakukan penelitian mengenai keefektifan pelaksanaan prinsip PSG pada SMK terutama pada SMK Negeri 1 Pangkalan Kerinci dan SMK Negeri 1
Ukui yang berada pada lingkungan Dinas Pendidikan Kabupaten Pelalawan. Kedua sekolah tersebut dianggap sebagai sekolah yang cukup maju pada daerah tersebut. Sehingga peneliti berkeinginan untuk mengetahui sejauh mana keefektifan pelaksanaan prinsip PSG pada sekolah tersebut.

\section{Metode Penelitian}

Jenis dan Desain Penelitian

Desain penelitian yang digunakan dalam penelitian ini adalah studi evaluasi dengan analisis deskriptif kuantitatif. Metode yang digunakan untuk mengukur keefektifan pelaksanaan prinsip PSG pada SMKN 1 Pangkalan Kerinci dan SMKN 1 Ukui peneliti menggunakan metode evaluasi CIPP (context, input, process, dan product) dari Stufflebeam dengan tujuan untuk melihat perbandingan tingkat keefektifan pelaksanaan prinsip PSG dari dua sekolah tersebut.

\section{Tempat dan Waktu Penelitian}

Penelitian ini dilaksanakan pada dua sekolah yang berada di lingkungan Dinas Pendidikan Kabupaten Pelalawan, Profinsi Riau, yaitu SMKN 1 Pangkalan Kerinci dan SMKN 1 Ukui. Kedua sekolah tersebut dipilih berdasarkan kemiripan dan kesetaraan kualitas dari sekolah tersebut dalam pelaksanaan PSG. Dan penelitian ini dilaksanakan dari awal November 2013 hingga Januari 2014. Hal ini dikarenakan pelaksanaan PRAKERIN berdasarkan prinsip PSG dimulai dari November sebagai awal persiapan keberangkatan sisiwa untuk terjun ke Dunia Usaha dan Industri (DU/DI) dan pelepasan keberangkatan pada bulan Desember. Sehingga peneliti dapat melihat langsung persiapan dan pelepasan siswa yang melaksanakan prinsip PSG. Sedangkan untuk penyebaran kuestioner mengenai pelaksanaan prinsip PSG dilakukan pada bulan Januari 2014 pada siswa kelas XII yang telah melakukan PSG pada tahun sebelumnya. Hal ini berdasarkan survai awal dari peneliti pada sekolah tersebut. 
Populasi

Populasi penelitian ini terdiri dari Kepala SMK, Waka DU/DI(Waka Humas), Waka Kurikulum, Ketua Jurusan masingmasing prodi, panitia PSG dan siswa kelas III pada SMK Negeri 1 Pangkalan Kerinci dan SMK Negeri 1 Ukui, kabupaten Pelalawan, Riau.

\section{Sampel}

Pengambilan sampel dengan menggunakan purposive sampling (sampel bertujuan), yakni mengambil perwakilan dari siswa yang telah melaksanakan PSG dan berasal dari jurusan yang sama yang ada di kelas III dari kedua sekolah tersebut. Jurusan yang menjadi perwakilan dari kedua sekolah yaitu Teknik Komputer Jarinagan (TKJ), Teknik Sepeda Motor (TSM), dan Teknik Kendaraan Bermotor (TKR). Sedangkan untuk subyek penelitian kepala SMK, waka DU/DI (waka Humas), Waka Kurikulum, ketua jurusan, dan panitia PSG. Pada penelitian ini jumlah subyek yang di teliti untuk siswa SMKN 1 Pangkalan Kerinci sebanyak 64 siswa, dan SMKN 1 Ukui sebanyak 59 siswa, 2 orang kepala SMK, 2 orang waka DU/DI (Humas), 2 orang waka Kurikulum, 4 orang ketua prodi masing-masing jurusan, dan 20 guru yang berperan dalam pelaksanaan PSG dari kedua sekolah tersebut.

\section{Teknik Pengumpulan Data}

Pengumpulan data dalam penelitian ini dengan menggunakan wawancara mendalam dilakukan kepada pihak sekolah yang terlibat dalam pelaksanaan PSG. Teknik kuesioner dengan teknik angket tertutup yang dikerjakan siswa dalam bentuk kuesioner. Dokumentasi dalam penelitian sebagai sumber nyata dan bukti konkrit dari hasil penelitian yang telah diperoleh peneliti.

\section{Instrumen Penelitian}

Instrumen yang digunakan dalam penelitian ini menggunakan kuesioner berbentuk isian yang digunakan untuk mem- peroleh data kuantitatif, dan instrument berupa pedoman wawancara, lembar observasi dan dokumentasi digunakan untuk menggali informasi lebih dalam mengenai pelaksanaan prinsip PSG pada SMKN 1 Pangkalan Kerinci dan SMKN 1 Ukui, sehingga dapat lebih mengungkap faktafakta yang ada di lapangan.

\section{Definisi Operasional Komponen Penelitian}

Dalam penelitian ini terdapat empat komponen penelitian, yaitu: (a) komponen konteks, (b) komponen input, (c) komponen proses, (d) komponen produk.

\section{Teknik Keabsahan Data}

Dalam penelitian ini keabsahan data dapat dilakukan dengan beberapa cara kredibilitas data, transferbilitas data, dan dependabilitas dan konfirmabilitas data yang ditempuh melalui pengauditan oleh pembimbing.

\section{Validitas dan Reliabilitas Data}

Instrumen yang diuji cobakan hanya kuesioner, sedangkan pedoman wawancara dan observasi dimantapkan melalui konsultasi dosen pembimbing. Uji coba instrumen dilaksanakan untuk mengetahui validitas dan reliabillitas instrumen agar hasil yang diperoleh mengungkap permasalahan yang meyakinkan.

Untuk pengujian kendala butir pada setiap faktornya digunakan tekhnik Alpha dari Cronbach. Dalam mengukur kesahihan dan keandalan instrument yang berbentuk kuesioner ini digunakan dengan bantuan SPSS for Windows.

\section{Teknik Analisis Data}

Data yang terkumpul akan dianalisis dengan analisis deskriptif kuantitatif. Analisis kuantitatif jika data dikumpulkan berupa angka-angka. Program yang digunakan untuk pengolahan data kuantitatif penelitian ini adalah SPSS for Windows. Selanjutnya data kuantitatif tersebut dianalisis secara deskriptif. 
Kriteria Keefektifan

Keefektifan dalam penelitian yang dilakukan peneliti adalah untuk melihat kesempuranaan proses pelaksanaan prinsip PSG sesuai dengan ketentuan yang berlaku. Sesuai dengan Arikunto (1998, p.246), maka kriteria keberhasilan atau keefektifan dapat dibagi menjadi efektif, cukup efektif, kurang efektif, dan tidak efektif. Hasil analisis akan dinilai dengan menggunakan skala interval (Siregar, 2010, p.136) yaitu suatu skala di mana objek atau kategori dapat diurutkan berdasarkan suatu atribut tertentu, di mana jarak atau interval antara tiap objek atau kategori sama.

Penilaian keefektifan setiap komponen penelitian didasarkan pada kategori yang disajikan pada Tabel 1.

Tabel 1. Skala Keefektifan Pelaksanaan Prinsip PSG pada

SMKN 1 Pangkalan Kerinci dan SMKN 1 Ukui

\begin{tabular}{ccc}
\hline No & $\begin{array}{c}\text { Persentase } \\
\text { Pencapaian }\end{array}$ & $\begin{array}{c}\text { Tingkat } \\
\text { Keefektifan }\end{array}$ \\
\hline 1 & $25 \%-43,75 \%$ & Tidak Efektif \\
2 & $43,76 \%-62,50 \%$ & Kurang Efektif \\
3 & $62,51 \%-81,25 \%$ & Efektif \\
4 & $81,26 \%-100 \%$ & Sangat Efektif \\
\hline
\end{tabular}

\section{Hasil Peneltian dan Pembahasan}

Pelaksanaan prinsip PSG pada SMKN 1 Pangkalan Kerinci tidak sepenuhnya dilaksanakan oleh ketua jurusan ataupun guru kejuruan akan tetapi atas kerjasama antara Humas, ketua jurusan, dan bebrapa guru adaptif dan normatif yang berperan sebagai pembimbing dalam pelaksanaan monitoring selama pelaksanaan prinsip PSG.

Relevansi pelaksanaan prinsip PSG dengan keahlian siswa di sekolah sejauh ini menurut ketua jurusan Tekhnik Komputer Jaringan siswa ditempatkan sesuai dengan jurusan yang siswa miliki namun tidak menutup kemungkinan terjadi sedikit penyimpangan. Hal ini dikarenakan lokasi praktik yang kurang memadai untuk jurusan yang dikuasai siswa. Untuk kategori keefektifan variabel Context untuk
SMKN 1 Pangkalan Kerinci adalah sebesar $84,38 \%$, sangat efektif

Keefektifan pelaksanaan prinsip program PSG ditinjau dari segi input dapat dilihat dari pengelolaan peserta didik, peranan tenaga kependidikan dalam mempersiapkan pelaksanaan prinsip PSG, pengelolaan kurikulum dalam mempersiapkan pelaksanaan prinsip PSG, kelengkapan sarana dan prasarana dalam mempersiapkan pelaksanaan prinsip PSG, dan pengelolaan pembiayaan prinsip PSG pada sekolah tersebut.

Dari segi kurikulum pelaksanaan prinsip PSG di SMKN 1 Pangkalan Kerinci terlaksana atas kerjasama dari pihak kurikulum, humas, kejuruan, dan guru yang berkontribusi di dalamnya. Untuk pembiayaan PSG pada tahun sebelumnya diembankan kepada siswa sepenuhnya dan dikelolala oleh pihak humas dan staff yang ada, namun pada tahun ajaran 2013-2014 pelaksanaan prinsip PSG dibebaskan dari pembiayaan yang ada.Hal ini sejalan dengan program pemerintah kabupaten Pelalawan yang telah menerapkan pendidikan gratis untuk seluruh masyarakat Pelalawan dari jenjang sekolah dasar hingga jenjang pendidikan menengah atas.

Berdasarkan kuesioner yang diberikan kepada siswa SMKN 1 Pangkalan Kerinci maka diperoleh persentase keefektifan pelaksanaan PSG dari segi input sebesar $78,82 \%$, sudah efektif.

Proses pelaksanaan prinsip PSG di SMKN 1 Pangkalan Kerinci diawali dengan pemetaan dunia industri pasangan yang akan melakukan kerja sama dengan sekolah dalam pelaksanaan prinsip PSG. Setelah pemetaan, dan mendapat persetujuan dari dunia insutri maka pihak sekolah khususnya humas melakukan penandatanganan MoU dengan pihak indutri untuk kerjasama jangka panjang sehingga bisa digunakan untuk beberapa kali periode pelaksanaan prinsip PSG. Pada SMKN 1 Pangkalan Kerinci MoU dibuat paling singkat untuk jangka waktu paling singkat 3 tahun dan paling lama 5 tahun kerjasama, kemudian dilakukan pembaharuan $\mathrm{MoU}$ kembali. 
Berdasarkan persentase keefektifan pelaksanaan PSG pada SMKN 1 Pangkalan Kerinci dari segi process yaitu $71,20 \%$, efektif karena berada pada skala interval antara $62,51 \%-81,25 \%$.

Keefektifan pelaksanaan prinsip PSG dapat dilihat dari product atau hasil dari pelaksanaan prinsip PSG tersebut, mulai dari peningkatan skill siswa sampai pada hasil prestasi akademik siswa. Selain itu, keefektifan pelaksanaan prinsip PSG juga dapat dilihat dari adanya kepercayaan dunia industri dalam merekrut lulusan yang SMKN 1 Pangkalan Kerinci yang telah melaksanakan prinsip PSG pada dunia indutri pasangan.Berdasarkan hasil wawancara yang diperoleh peneliti pada SMKN 1 Pangkalan Kerinci yang secara keseluruhan mengatakan bahwa setelah pelaksanaan prinsip PSG siswa lebih trampil dan siap menghadapi Ujian Nasional serta terlihat adanya peningkatan kualitas akademik siswa.

Berdasarkan kuesioner yang disebarkan pada 64 siswa SMKN 1 Pangkalan Kerinci dari jurusan TKJ dan TMO, keefektifan pelaksanaan PSG pada SMKN 1 Pangkalan Kerinci dari segi product sangat efektif karena memiliki persentase keefektifan pelaksanaan prinsip PSG sebesar $82,55 \%$.

Prinsip Pendidikan Sistem Ganda (PSG) pada SMKN 1 Ukui dilaksanakan atas kerjasama panitia pelaksanaan prinsip PSG yang telah ditetapkan berdasarkan hasil rapat saat persiapan pelaksanaan prinsip PSG oleh seluruh komponen yang ada di sekolah. Kepanitiaan tersebut di bawah tanggung jawab kepala sekolah SMKN 1 Ukui, dan diketuai oleh wakil kepala bagian humas. Selain itu, peranan wakil kepala bagian kurikulum, ketua jurusan, dan semua guru yang ada di sekolah juga sangat mempengaruhi kegiatan prinsip PSG pada SMKN 1 Ukui, seperti yang diungkapkan oleh wakil kepala bagian humas yang mengatakan bahwa pelaksanaan prinsip PSG siswa SMKN 1 Ukui terlaksana berdasarkan kerjasama semua pihak yang ada di sekolah. Selain itu, wakil kepala bagian humas juga mengatakan bahwa struktur organisasi pelaksanaan prinsip PSG pada SMKN 1 Ukui dibuat berdasarkan keputusan rapat bersama seluruh komponen sekolah. Untuk kategori keefektifan berdasarkan kuesioner yang diisi siswa diperoleh persentase variabel Context untuk SMKN 1 Ukui adalah sebesar $85,81 \%$, sangat efektif

Keefektifan pelaksanaan prinsip program PSG ditinjau dari segi input pada SMK Negeri 1 Ukui dapat dilihat dari pengelolaan peserta didik, peranan tenaga kependidikan dalam mempersiapkan pelaksanaan prinsip PSG, pengelolaan kurikulum dalam mempersiapkan pelaksanaan prinsip PSG, kelengkapan sarana dan prasarana dalam mempersiapkan pelaksanaan prinsip PSG, dan pengelolaan pembiayaan prinsip PSG pada sekolah tersebut. SMKN 1 Ukui mempersiapkan pelaksanaan prinsip PSG diawali dengan rapat pembentukan panitia pelaksana, seperti yang dikemukakan kepala SMKN 1 Ukui yang mengatakan bahwa kepala sekolah beserta staffnya melaksanakan rapat persiapan pelaksanaan prinsip PSG beberapa bulan sebelum pelaksanaan prinsip PSG terutama pada rapat awal semester dan beberapa saat menjelang pelaksanaan prinsip PSG tersebut. Rapat persiapan pelaksanaan prinsip PSG menurut kepala SMKN 1 Ukui bertujuan untuk membentuk kepanitian pelaksanaan prinsip PSG yang di ketua oleh wakil kepala bagian humas.

Dari segi kurikulum menurut wakil kepala bagian kurikulum pelaksanaan prinsip PSG di SMKN 1 Ukui terlaksana atas kerjasama dari seluruh jajaran kepanitiaan yang telah ditunjuk dan bagian kurikulum berperan sebagai pengatur terlaksananya prinsip PSG dengan menyesuaikan kegiatan pembelajaran di sekolah dengan pelaksanaan prinsip PSG dan bagian kurikulum juga berperan untuk mengelola jadwal yang telah diajukan humas serta memfasilitasi segala keperluan yang dibutuhkan pihak humas terutama yang berhubungan dengan guru dan siswa.

Untuk pembiayaan pelaksanaan prinsip PSG seperti yang tejadi pada SMKN 1 Pangkalan Kerinci, pada SMKN 1 Ukui pembiayaan pelaksanaan prinsip PSG pada 
tahun sebelumnya juga di bebankan kepada siswa sepenuhnya dan di kelolala oleh pihak humas dan staff yang ada, namun pada tahun ajaran 2013-2014 pelaksanaan prinsip PSG dibebaskan dari pembiayaan yang ada. Hal ini sejalan dengan program pemerintah kabupaten Pelalawan yang telah menerapkan pendidikan gratis untuk seluruh masyarakat Pelalawan dari jenjang sekolah dasar hingga jenjang pendidikan menengah atas.

Berdasarkan kuesioner yang diberikan kepada siswa SMK Negeri 1 Pangkalan Kerinci maka diperoleh persentase keefektifan pelaksanaan PSG dari segi input sebesar $78,77 \%$, sudah efektif.

Proses pelaksanaan prinsip PSG di SMKN 1 Ukui diawali dengan pemetaan dunia industri pasangan yang akan melakukan kerja sama dengan sekolah dalam pelaksanaan prinsip PSG. Pemetaan dilakukan oleh panitia pelaksanaan prinsip PSG untuk menjamin kesesuaian dunia industri pasangan dengan jurusan yang dimiliki oleh siswa.

Jadwal pelaksanaan prinsip PSG tersebut dikonfirmasikan oleh humas kepada bagian kurikulum yang kemudian akan mengelola jadawal pelaksanaan prinsip PSG dengan proses belajar mengajar disekolah. Penetapan guru pembimbing siswa yang melaksanakan prinsip PSG juga ditetapkan oleh pihak kurikulum karena disesuaikan dengan jumlah jam mengajar guru yang ada sehingga pembagian tugas tenaga pendidik dapat dibagi dengan adil dan merata sesuai dengan kinerja masingmasing guru.

Sebelum keberangkatan siswa dalam pelaksanaan prinsip PSG terlebih dahulu sekolah memberikan pembekalan. Pada SMKN 1 Ukui pembekalan siswa dalam melaksanakan prinsip PSG diberikan sebanyak 2 kali. Pembekalan untuk siswa yang akan melaksanakan prinsip PSG dilaksanakan minimal 2 hari sebelum keberangkatan siswa.

Berdasarkan persentase keefektifan pelaksanaan PSG oleh SMKN 1 Ukui dari segi process yaitu $71,08 \%$, sudah efektif.
Keefektifan pelaksanaan prinsip PSG pada SMK Negeri 1 Ukui dapat dilihat dari product atau hasil dari pelaksanaan prinsip PSG tersebut, mulai dari peningkatan skill siswa sampai pada hasil prestasi akademik siswa. Selain itu, keefektifan pelaksanaan prinsip PSG juga dapat dilihat dari adanya kepercayaan dunia industri dalam merekrut lulusan SMKN 1 Ukui yang telah melaksanakan prinsip PSG pada dunia indutri pasangan. Berdasarkan hasil wawancara yang diperoleh peneliti pada kepanitiaan pelaksanaan SMKN 1 Ukui yang secara keseluruhan mengatakan bahwa setelah pelaksanaan prinsip PSG sebagian besar kemampuan siswa dibidang kejuruannya meningkat.

Berdasarkan data yang diperoleh dari penyebaran kuesioner pada siswa SMKN 1 Ukui dari jurusan TKJ dan TMO, keefektifan pelaksanaan PSG pada SMKN 1 Ukui dari segi product sangat efektif karena memiliki persentase keefektifan pelaksanaan prinsip PSG sebesar 83,33\%.

\section{Context}

Secara organisatoris manajemen pelaksanaan prinsip PSG di bawah kendali langsung dari wakil kepala bidang humas dan secara operasional ditangani oleh panitia khusus. Secara umum tugas panitia pelaksana prinsip PSG di masing-masing sekolah sama, yaitu: dimulai dari perencanaan pelaksanaan prinsip PSG, peng-organisasian pelaksanaan prinsip PSG, pelaksanaan prinsip PSG, dan evaluasi pelaksanaan prinsip PSG. Seluruh panitia pelaksana prinsip PSG bertanggung jawab kepada kepala SMK.

Pelaksanaan prinsip PSG merupakan model penyelenggaraan pendidikan kejuruan dimana perencanaan dan pelaksanaan pendidikan diwujudkan dalam bentuk kemitraan antara dunia kerja dan sekolah. Menurut Anwar (2012, p.48) PSG dilaksanakan di dua tempat berbeda, tetapi terkait dan berkesinambungan, pertama, pembelajaran yang bersifat teoritis dan kognitif, dan kademis dilaksanankan berbasis sekolah (school based learning) dan pembelajaran 
bersifat psikomotorik, vocasional, dan berbasis kerja (work based learning) berlangsung di dunia industri. Adanya perbedaan budaya yang mendasar antara lingkungan sekolah dengan dunia kerja, mengharuskan sekolah untuk benar-benar mempersiapkan siswanya sebelum masuk dunia industri. Selain itu seringnya terjadi ketidaksesuaian jurusan dan skill siswa dengan dunia industri juga mengharuskan sekolah untuk lebih selektif dalam menjalin kerjasama dengan dunia industri. Setiap SMK melaksanakan pemetaan terlebih dahulu terhadap dunia industri untuk menjamin relevansi antara jurusan dan skill siswa dengan dunia industri. Pada SMKN 1 Pangkalan Kerinci pemetaan dunia industri tidak sepenuhnya dilaksanakan oleh sekolah, hal ini untuk mengurangi permasalahan yang timbul dalam pelaksanaan prinsip PSG sehingga sekolah memberikan kebebasan kepada siswa untuk mencari dunia industri pasangan untuk pelaksanaan prinsip PSG, kemudian melaporkan kepada sekolah dan dilakukan pengajuan kerjasama jangka panjang oleh sekolah khususnya bagian humas kepada dunia industri. Dengan alasan yang sama, SMKN 1 Ukui juga tidak sepenuhnya melaksanakan pemetaan dunia industri untuk melaksanakan prinsip PSG, sekolah juga menyerahkan kebebasan kepada siswa untuk mencari dunia industri pasangan untuk melaksanakan prinsip PSG dengan ketentuan sesuai dengan ketetapan yang ada dan tidak keluar dari jurusan siswa. Pengajuan surat permohonan kerjasama antara sekolah dan dunia industri dilaksanakan sepenuhnya oleh wakil kepala bidang humas.

Berdasarkan pengamatan dan observasi yang dilakukan peneliti dari bulan Oktober 2013 hingga Januari 2014, peneliti berpendapat bahwa peranan struktur organisai pelaksana prinsip PSG SMKN 1 Pangkalan Kerinci lebih efektif bila dibandingkan dengan SMK Negeri 1 Ukui. Namun berdasarkan penilain siswa yang melaksanakan program pelaksanaan prinsip PSG SMKN 1 Ukui jauh lebih efektif bila dibandingkan dengan SMKN 1 Pangkalan
Kerinci, seperti yang terlihat pada Gambar 1. Penilaian diambil berdasarkan isian kuesioner yang disebarkan oleh pe-neliti kepada siswa.

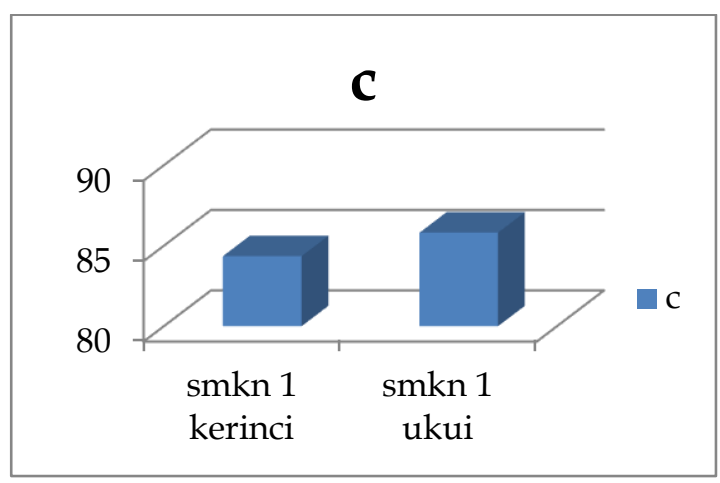

Gambar 1. Diagram Perbandingan

Keefektifan Pelaksanaan Prinsip

PSG dari Aspek Context pada

SMKN 1 Pangkalan Kerinci (1) dan SMKN 1 Ukui (2)

Input

Pengelolaan peserta didik sebagai pelaksana prinsip PSG pada SMKN 1 Pangkalan Kerinci dan SMKN 1 Ukui dimulai dari siswa yang berada di kelas I, dengan memberikan gambaran pelaksanaan prinsip PSG pada kelas II nantinya. Sekolah juga melatih kemampuan siswa dalam praktik kejuruan sehingga siswa siap untuk memasuki dunia kerja. Seperti yang diungkapkan oleh ketua jurusan TKJ SMK Negeri 1 Pangkalan Kerinci yang mengatakan bahawa dari awal masuk SMK siswa diberi gambaran perbedaan pendidikan SMK dan SMU dimana pada pendidikan SMK siswa akan menemukan proses belajar di dua tempat sekolah dan dunia industri yang disebut dengan magang. Hal serupa juga dikemukan oleh wakil kepala bidang humas SMKN 1 Ukui yang menyatakan bahwa pada saat orientasi siswa baru, siswa diberi gambaran bahwa pada saat kelas II mereka akan melaksanakan praktik kerja industri. Peserta didik yang melaksanakan prinsip PSG adalah siswa kelas II SMK semua jurusan.

Pelaksanaan prinsip PSG tidak hanya menjadi tanggung jawab humas dan kurikulum namun seluruh komponen di seko- 
lah memiliki peranan yang sama dalam mempersiapkan siswa. Seluruh siswa diberikan materi yang sesauai dengan jurusan untuk memantapkan kesiapan siswa dalam melaksanakan prinsip PSG.SMKN 1 Pangkalan Kerinci mewajibkan kepada seluruh guru jurusan melaksanakan pratikum minimal $2 x$ dalam seminggu untuk menoptimalkan kemampuan siswa. Menurut Anwar (2012, p.49) yang mengatakan bahwa sekolah hanya dapat memberikan kemampuan dasar kejuruan yang kuat, sehingga dengan bekal kemampuan dasar kejuruan yang dapat membantu siswa dalam mendalami pelatihan kerja yang lebih kompleks dan spesifik di dunia kerja. Dalam hal ini, SMKN 1 Ukui juga melaksanakan hal yang sama. Berdasarkan penelitian yang dilakukan peneliti pada bulan oktober 2013 hingga januari 2014 maka peneliti menyimpulkan bahwa sebagai sekolah menengah kejuruan SMKN 1 Pangkalan Kerinci dan SMKN 1 Ukui telah memiliki tenaga kependidikan yang memadai sesuai dengan jurusan yang ada.

Peranan kurikulum dalam mempersiapkan pelaksanaan prinsip PSG memiliki peranan penting, diantaranya untuk merencanakan pelaksanaan prinsip PSG, pelaksanaan prinsip PSG, dan evaluasi pelaksanaan prinsip PSG. Kurikulum SMKN 1 Pangkalan Kerinci dan SMKN 1 Ukui memiliki peranan yang sama dalam mempersiapkan pelaksanaan prinsip PSG. Peneliti menyimpulkan bahwa masing-masing sekolah tersebut memiliki peranan kurikulum yang sama seperti, penetapan waktu pelaksanaan prinsip PSG, penentuan guru pembimbing, dan mengelola nilai hasil evaluasi pelaksanaan prinsip PSG. Wakil kepala bidang kurikulum SMKN 1 Ukui mengatakan bahwa beliau berperan dalam mengelola waktu keberangkatan siswa pelaksana prinsip PSG, pengelolaan pembimbing dan mengelola nilai pelaksanaan prinsip PSG siswa. Seluruh kegiatan yang dilaksanakan pengelola kurikulum di sekolah harus mengikuti kalender pendidikan pada setiap tahun ajaran, guna untuk mengetahui permulaan tahun ajaran, minggu efektif, dan waktu belajar efektif dan libur.
Peranan sarana dan prasarana dalam mempersiapkan siswa untuk melaksanakan prinsip PSG sangatlah penting, dikarenakan siswa dipersiapkan kemampuannya dengan melakukan praktik dan pembelajaran dengan menggunakan fasilitas atau sarana dan prasarana yang tersedia di sekolah. Peneliti melihat untuk kelengkapan fasilitas atau sarana dan prasarana belajar di sekolah SMKN 1 Pangkalan Kerinci memiliki fasilitas yang lebih lengkap bila dibandingkan dengan fasilitas yang ada pada SMKN 1 Ukui. Peneliti beranggapan bahwa hal ini terjadi karena lamanya waktu operasi SMKN 1 Pangkalan Kerinci daripada SMKN 1 Ukui, karena SMKN 1 Pangkalan Kerinci sudah berdiri dari tahun 2002 dan SMKN 1 Ukui berdiri semenjak tahun 2009. Lamanya operasi suatu sekolah mempengaruhi kelengkapan fasilitas yang ada pada sekolah tersebut. Namun untuk sarana dan prasarana jurusan TKJ, TMO, dan TKR dua sekoalh ini sudah memiliki fasilitas yang hampir sama, seperti laboratorium komputer untuk jurusan TKJ, dan bengkel untuk jurusan TMO dan TKR. Ini merupakan salah satu alasan yang mendasar bagi peneliti untuk menggunakan siswa yang ada pada 3 jurusan tersebut sebagai sampel dari penelitian.

Pemerintah kabupaten pelalawan mulai tahun ajaran 2013-2014 memberikan fasilitas pendidikan gratis untuk seluruh siswa mulai dari tingkat SD hingga SMU/ SMK. Oleh karena itu, dalam pelaksanaan PSG di lingkungan sekolah kejuruan kabupaten Pelalawan mulai tahun ajaran 20132014 siswa dibebaskan dari seluruh biaya yang ada. Pada tahun-tahun sebelumnya, dalam pelaksanaan prinsip PSG siswa dibebankan biaya oleh pihak sekolah, dan siswa diwajibkan melunasi pembiayaan tersebut sebelum jadwal keberangkatan. Pada SMKN 1 Pangkalan Kerinci, pengelolaan pembiayaan pelaksanaan prinsip PSG dikelola oleh bendahara umum sekolah bersama bendahara komite, sedangkan pada SMKN 1 Ukui pembiayaan pelaksanaan prinsip PSG dikelola oleh kajur dan diserahkan kepada humas. Dalam pelak- 
sanaan pendidikan gratis seluruh pembiayaan yang ada di sekolah ditangani oleh bendahara umum sekolah. Siswa hanya diminta mempersiapkan diri dan kemampuannya untuk melaksanakan prinsip PSG.

Berdasarkan rata-rata mean dari hasil isian kuesioner oleh siswa pelaksana prinsip program PSG dari segi input disajikan pada Gambar 2.

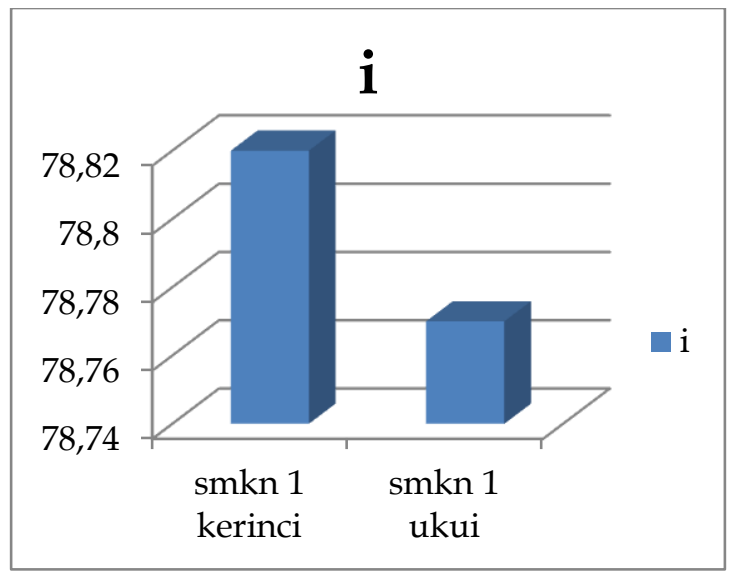

Gambar 2. Diagram Perbandingan

Keefektifan Pelaksanaan Prinsip

PSG dari Aspek Input pada

SMKN 1 Pangkalan Kerinci (1) dan SMKN 1 Ukui (2)

Dari diagram data kuesioner diatas dapat dilihat bahwa SMKN 1 Pangkalan Kerinci memiliki kualitas keefektifan pelaksanaan prinsip PSG lebih efektif dibandingkan SMKN 1 Ukui. Hal ini sesuai dengan pengmatan peneliti selama melaksanakan penelitian, SMKN 1 Pangkalan Kerinci memiliki input yang lebih baik daripada SMKN 1 Ukui hanya saja pengelolaannya yang kurang maksimal mengingat jumlah siswa dan jurusan yang terlalu banyak pada sekolah tersebut. SMKN 1 Pangkalan Kerinci memiliki 17 jurusan sedangkan SMKN 1 Ukui hanya memiliki 4 jurusan.

\section{Process}

Persiapan pelaksanaan prinsip PSG diawali dengan rapat pembentukan panitia pelaksana prinsip PSG, seperti yang diungkapakan oleh kepala SMKN 1 Ukui yang mengatakan bahwa, sebelum pelaksanaan prinsip PSG sekolah terlebih dahulu mengadakan rapat pembentukan panitia pelaksanaan prinsip PSG dengan mempercayakan pelaksanaannys kepada humas di bawah pertanggungjawaban kepala sekolah. Selain pembentukan panitia persiapan pelaksanaan prinsip PSG juga dilakukan dari proses belajar mengajar di kelas oleh guru produktif. Guru harus memiliki kemampuan yang optimal guna untuk mempersiapkan kemampuan kerja siswa untuk pelaksanaan prinsip PSG. Kesiapan guru dalam mengajar dapat dilihat dari kelengkapan bahan ajar yang mereka miliki, penguasaan materi, dan interaksinya kepada siswa. Pada SMKN 1 Pangkalan Kerinci dan SMKN 1 Ukui guru produktif sudah memiliki bahan ajar yang memadai dalam proses belajar mengajar maupun praktik lapangan.

Penyeimbangan pendidikan siswa SMK yang diperoleh di dunia industri dan sekolah merupakan tujuan utama dari pelaksanaan prinsip PSG, untuk itu masingmasing sekolah harus memenuhi standar yang ada, mulai dari tenaga pengajar dan fasilitas lainnya untuk mempersiapkan siswa pelaksana prinsip PSG. Dan masingmasing sekolah, SMKN 1 Pangkalan Kerinci dan SMKN 1 Ukui juga sudah memiliki guru produktif yang sesuai dengan jurusan yang ada.

Sebelum pelaksanaan prinsip PSG siswa diberi pembekalan oleh pihak jurusan dan sekolah, guna untuk memantapkan kesiapan siswa sebelum turun ke dunia industri. Untuk SMKN 1 Pangkalan Kerinci pembekalan diberikan minimal 2 kali. Pertama pembekalan di masing-masing jurusan oleh ketua jurusan dan yang kedua oleh pihak sekolah yakni humas, kurikulum, kesiswaan, dan diberi pengrahan oleh perwakilan dari Dinas Pendidikan. Pada saat pembekalan siswa juga diwajibkan menanda tangani surat perjanjian yang mewajibkan siswa untuk bertanggung jawab terhadap permasalahan yang ditimbulkan oleh siswa di dunia industri. SMKN 1 Ukui memberikan pembekalan pada siswa beberapa hari sebelum keberangkatan yang diberikan oleh masing-masing jurusan dan pihak sekolah. Berbeda dengan SMKN 1 
Pangkalan Kerinci, di SMKN 1 Ukui pembekalan siswa pelaksana PSG tidak dihadiri oleh perwakilan dari Dinas Pendidkan, dengan alasan letak geografis yang jauh dari kabupaten. Namun SMK Negeri 1 Ukui juga mewajibkan siswa untuk menandatangani surat perjanjian seperti yang dilaksanakan oleh SMKN 1 Pangkalan Kerinci, hal ini untuk mencegah permasalahan yang timbul pada saat pelaksanaan prinsip PSG.

Setelah pemberian pembekalan sebelum keberangkatan pelaksanaan prinsip PSG, siswa diberikan guru pembimbing pelaksana prinsip PSG yang telah ditetapkan oleh wakil kepala bidang kurikulum dan humas guna untuk memonitor kegiatan pelaksanaan prinsip PSG siswa. Masing-masing guru pembimbing diberi kepercayaan untuk membimbing beberapa orang siswa. Pada SMKN 1 Pangkalan Kerinci 1 pembimbing diberi kepercayaan untuk membimbing 5 sampai dengan 10 siswa sedangkan untuk SMKN 1 Ukui 1 pembimbing diberi kepercayaan 4 sampai dengan 6 siswa. Jumlah monitoring dari masing-masing sekolah juga berbeda untuk SMKN 1 Pangkalan Kerinci sebanyak 6 kali monitoring dan SMKN 1 Ukui sebanyak 5 kali. Namun bila terjadi permasalahan pada siswa saat melaksanakan prinsip PSG guru pembimbing wajib untuk mengunjungi siswa diluar jadwal monitoring yang sudah ditentukan. Salah seorang siswa SMKN 1 jurusan TKJ mengaku bahawa selama proses pelaksanaan prinsip PSG hanya dimonitor sekali oleh guru pembimbing. Hal yang sama juga dikemukakan oleh beberapa siswa dari jurusan TMO dan TKR yang mengatakan bahwa mereka dimonitor tidak sesuai dengan jadwal yang ada, hal ini sangat kontras dengan pengakuan dari pihak sekolah yang sudah menjadwalkan minimal 6 kali monitoring. Peneliti beranggapan pelaksanaan monitoring belum terlaksana sepenuhnya seperti yang dijadwalkan sekolah. Pelaksanaan monitoring pada SMKN 1 Ukui juga tidak terlaksana secara maksimal. Seperti informasi yang didapat peneliti dari beberpa orang siswa yang mengatakan bahwa mo- nitoring tidak sebanyak yang dijadwalkan sekolah.

Waktu pelaksanaan prinsip PSG yang berbeda antara SMKN 1 Pangkalan Kerinci dan SMKN 1 Ukui menghasilkan pembelajaran yang berbeda pula bagi siswa selama pelaksanaan prinsip PSG. Pada SMK Negeri 1 Ukui pelaksanaan prinsip PSG dilaksanakan pada 3 bulan akhir semester ganjil dikelas II hingga 3 bulan awal semester genap di kelas II. Sekolah berharap pada 3 bulan diawal semester ganjil dan 3 bulan diakhir semester genap siswa dapat melaksanakan proses belajar mengajar seperti biasa sehingga seimbang antara proses belajar disekolah dan di dunia industri. SMKN 1 Ukui melaksanakan prinsip PSG pada semester genap di kelas II selam 6 bulan penuh, untuk memenuhi proses belajar mengajar disekolah pada semester genap sekolah membekali siswa dengan modul dan lembar kerja siswa (LKS) untuk menyeimbangkan proses belajar di sekolah dan dunia industri. Peneliti berpendapat bahwa pelaksanaan prinsip PSG dan penyeimbangan proses belajar siswa yang dilakukan SMKN 1 Pangkalan Kerinci jauh lebih efektif dibandingkan dengan sistem yang dilaksanakan SMKN 1 Ukui. Kepala SMKN 1 Ukui berpendapat bahwa dengan pelaksanaan prinsip PSG 1 semester penuh dapat mengoptimalkan hasil dari pelaksanaan prinsip PSG tersebut. Begitu pula dengan pendapat yang dikemukakan oleh kepala SMKN 1 Pangkalan kerinci yang mengharapkan siswa dapat optimal dalam pelaksanaan prinsip PSG dan pendidikan di sekolah. Menurut panduan kurikulum tingkat satuan pendidikan SMK (2006, p.12) yang mengatakan bahwa durasi pelatihan di dunia industri dilaksanakan 4 (empat) bulan sampai dengan 1 (satu) tahun pada industri dalam atau luar negeri. Masing-masing sekolah diberi kebebasan untuk memprogram pelaksanaan prinsip PSG dengan acuan ketetapan dari kurikulum yang telah ada.

Selama pelaksanaan prinsip PSG siswa diperkenalkan dengan dunia kerja dan industri. Siswa mengaplikasikan ilmu yang diperoleh di sekolah dan memprak- 
tikkannya di dunia industri. Namun pada pelaksanaannya banyak dunia industri tidak memberikan kepercayaan sepenuhnya kepada siswa dengan alasan kurang optimalnya kinerja siswa. Oleh karena itu, setiap siswa diberi tutor atau pendamping dari pihak dunia industri untuk mendampingi siswa selama pelaksanaan prinsip PSG. Salah seorang siswa jurusan TKJ dari SMK Negeri 1 Pangkalan Kerinci mengatakan bahwa dalam pelaksanaan prinsip PSG siswa merasa kegiatan yang dilakukan pada dunia industri tidak sesuai dengan ilmu yang diperoleh di sekolah. Hal ini juga dikemukakan oleh ketua jurusan TKJ SMK Negeri 1 Pangkalan Kerinci yang mengatakan bahwa sebagian siswa pelaksana prinsip PSG tidak mempraktikkan ilmu yang mereka dapat disekolah.

Kepala SMKN 1 Ukui juga mengatakan bahwa tujuan utama dari pelaksanaan prinsip PSG adalah untuk memperkenalkan dunia kerja kepada siswa. Ketidaksesuaian ilmu yang diberikan sekolah dengan praktik yang dilakukan di dunia industri sering terjadi pada saat pelaksanaan prinsip PSG khusunya jurusan TKJ karena kurangnya daya tampung dan kepercayaan dunia industri kepada siswa dalam melaksanakan tugasnya. Namun hal itu dapat diminimalisir dengan menyaksikan langsung cara kerja dari dunia industri, sehingga siswa dapat belajar dari apa yang dilihat.

Penilaian kerja siswa pada saat pelaksanaan prinsip PSG dilakukan oleh dua pihak yaitu pihak industri dan sekolah. Dari dunia industri diberikan oleh tutor pendamping dan dari sekolah diberikan oleh guru pembimbing. Peneliti melihat bahwa untuk sistem penilaian SMKN 1 Pangkalan Kerinci dan SMKN 1 Ukui memiliki sistematika yang sama, nilai yang didapat dari pendamping dari dunia industri dan guru pembimbing dikelola oleh jurusan dan diserahkan kepada pihak kurikulum hingga diperoleh nilai akhir yang digunakan sebagai nilai pelaksanaan prinsip PSG.

Berikut deskripsi data process pelaksanaan prinsip PSG SMK Negeri 1 Pangkalan Kerinci dan SMK Negeri 1 Ukui.

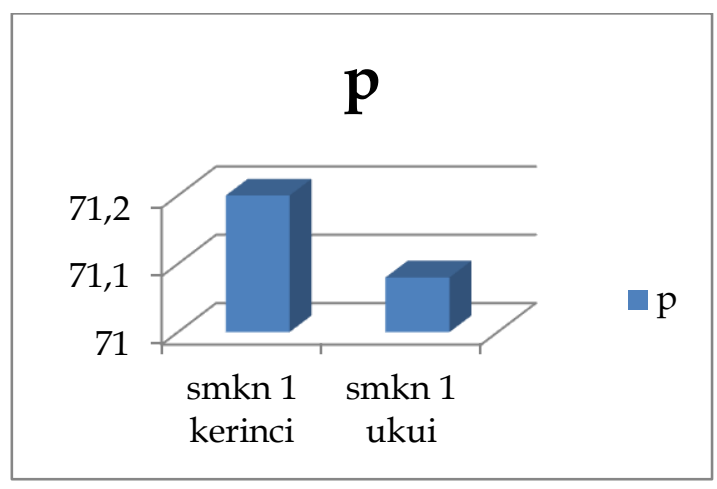

Gambar 3. Diagram Perbandingan Keefektifan Pelaksanaan Prinsip PSG dari Aspek Process pada SMKN 1 Pangkalan Kerinci (1) dan SMKN 1 Ukui (2)

Process pelaksanaan prinsip PSG pada SMKN 1 Pangkalan Kerinci dan SMKN 1 Ukui berdasarkankan pengamatan dan obseravasi peneliti sebenarnya tidak terlalu berbeda namun bila dilihat dari data yang diperoleh dari pengisian kuesioner oleh siswa, maka terlihat perbedaan yang sangat jelas bahwa SMKN 1 Ukui berada jauh di bawah SMKN 1 Pangkalan Kerinci.

\section{Product}

Pelaksanaan prinsip PSG diharapkan dapat meningkatkan hasil belajar siswa, meningkatkan kemampuan siswa dalam dunia kerja, dan meningkatkan kepercayaan diri siswa dalam menghadapi Ujian Nasional. Berdasarkan kuesioner yang disebarkan kepada siswa SMKN 1 Pangkalan Kerinci dan SMKN 1 Ukui maka dapat dilihat bahwa sebagian besar siswa merasa siap menghadapi Ujian Nasional dan memiliki kemampuan yang meningkat dalam pelajaran produktif. Anwar (2012, p.51) mengungkapkan bahwa PSG dapat memberikan nilai tambah pada siswa, yaitu (1) hasil belajar akan lebih bermakna, karena setelah tamat mereka akan memiliki keahlian sebagia bekal untuk mengembangkan diri secara berkelanjutan, (2) waktu untuk mencapai keahlian professional menjadi singkat, (3) keahlian profesioanal yang diperoleh melalui PSG dapat mengangkat harga diri dan kepercayaan diri peserta didik yang selanjutnya dapat mendorong mereka untuk meningkatkan ke- 
ahlian profesionalnya pada tingkat yang lebih tinggi. Berikut deskripsi data persentase product untuk pelaksanaan PSG pada SMK Negeri 1 Pangkalan Kerinci dan SMK Negeri 1 Ukui, yaitu:

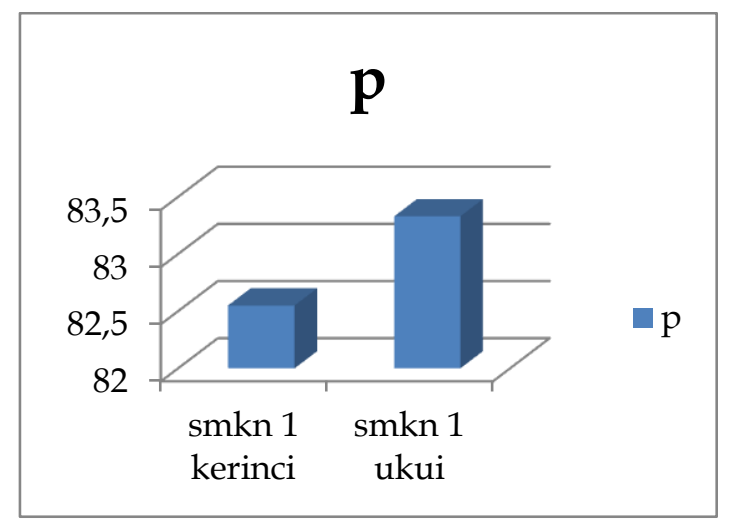

Gambar 4. Diagram Perbandingan Keefektifan Pelaksanaan Prinsip PSG dari AspekProduct pada SMKN 1 Pangkalan Kerinci (1) dan SMKN 1 Ukui (2)

Hasil penelitian untuk aspek product dari pelaksanaan prinsip program PSG pada SMKN 1 Pangkalan Kerinci dan SMKN 1 Ukui dapat disimpulkan bahwa SMKN 1 Ukui lebih efektif dibandingkan dengan SMKN 1 Pangkalan Kerinci.

Pada dasarnya berdasarkan hasil penelitian peneliti dari data wawncara, dokumen, dan observasi pelaksanaan prinsip PSG pada SMKN 1 Pangkalan Kerinci dan SMKN 1 Ukui memiliki kesamaan dan sudah sesuai dengan prosedur yang ada namun untuk hasil penelitian dari data statistika deskriptif terlihat jelas bahwa keefektifan pelaksanaan prinsip PSG pada SMKN 1 Ukui lebih efektif dari pada SMKN 1 Pangakalan Kerinci. Hal ini dapat dilihat dari diagram keefektifan pelaksanaan prinsip PSG secara keseluruhan berdasarkan aspek CIPP berikut:

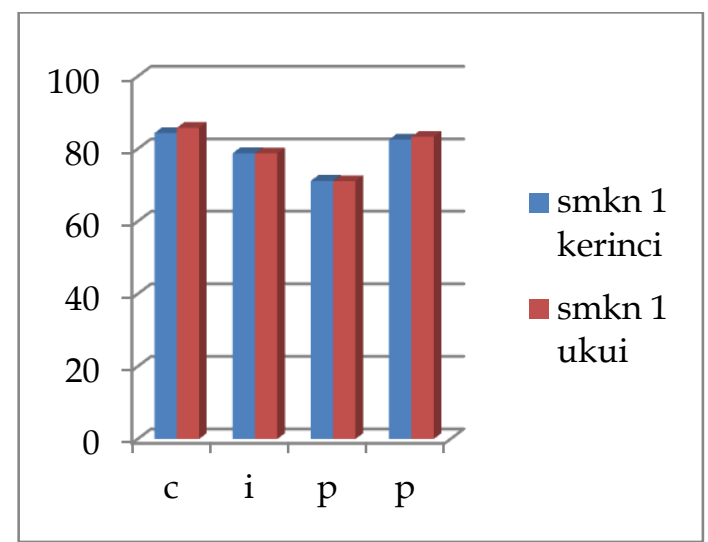

Gambar 5. Perbandingan Keefektifan Pelaksanaan Prinsip PSG pada SMKN 1 Pangkalan Kerinci dan SMKN 1 Ukui berdasarkan aspek CIPP

\section{Simpulan dan Saran}

Simpulan

Keefektifan pelaksanaan pendidikan sistem ganda (PSG) pada SMK Negeri 1 Pangkalan Kerinci dan SMK Negeri 1 Ukui dilihat dari aspek context, input, process dan product, dapat disimpulkan sebagai berikut: (1) ditinjau dari sisi context organisasi penyelenggara pelaksanaan prinsip PSG sudah terstruktur meskipun struktur yang ada pada SMKN 1 Pangkalan Kerinci sedikit berbeda dengan struktur yang ada pada SMKN 1 Ukui. Dan berdasarkan hasil olah data dari kuesioner yang diisi siswa SMKN 1 Ukui lebih efektif daripada SMKN 1 Pangkalan Kerinci, (2) ditinjau dari context relevansi pelaksanaan prinsip PSG dengan keahlian siswa belum dapat terpenuhi sepenuhnya, dikarenakan kuota penerimaan siswa PSG pada dunia industri yang terbatas, (3) ditinjau dari sisi input, manajemen pengelolaan peserta didik masing-masing sekolah sudah baik, hal ini berdasarkan pengamatan peneliti selama melakasanakan penelitian di sekolah, (4) ditinjau dari input tenaga kependidikan masing-masing sekolah sudah cukup memadai, (5) ditinjau dari input persiapan siswa dalam menghadapi PRAKERIN sebagai wujud pelaksanaan prinsip PSG sudah sesuai dengan prosedur yang ada, (6) ditinjau dari input kurikulum masing-masing 
sekolah sudah memiliki dasar dan kurikulum yang sama yang diberlakukan oleh Dinas Pendidikan Kabupaten Pelalawan, (7) ditinjau dari input sarana dan prasarana SMKN 1 Pangkalan Kerinci memiliki sarana yang lebih baik daripada SMKN 1 Ukui dan sudah efektif dalam pengelolaannya dibandingkan SMKN 1 Ukui, (8) ditinjau dari input pembiayaan pelaksanaan prinsip PSG pada masing-masing sekolah memiliki kebijakan yang sama, yaitu untuk saat ini sudah tidak dibebankan kepada siswa sesuai dengan kebijakan pemerintah daerah yang telah melaksanakan program sekolah gratis untuk tingkat SD, SMP, SMA, dan SMK sekabupaten pelalawan. Sehingga untuk pelaksanaan PRAKERIN sebagai perwujudan prinsip PSG siswa juga dibebaskan dari biaya, (9) ditinjau dari sisi process pelaksanaan PSG pada SMKN 1 Pangkalan Kerinci dan SMKN 1 Ukui mempunyai tingkat keefektifan yang cukup baik. Proses persiapan pelaksanaan PSG sudah terstruktur dan terencana dengan baik oleh pihak sekolah, namun pelaksanaan dari persiapan tersebut yang tidak maksimal. Proses pembelajaran di sekolah dalam mempersiapkan siswa melaksanakan prinsip PSG sudah cukup baik, peranan guru produktif untuk persiapan siswa juga sudah maksimal, (10) ditinjau dari proses PSG di dunia industri tidak semuanya berjalan sesuai dengan harapan siswa. Siswa tidak diberikan kepercayaan sepenuhnya oleh dunia industri dalam pelaksanaan PSG, sehingga siswa tidak secara maksimal dapat mengaplikasikan ilmu yang didapat dari sekolah. Untuk tingkat keefektifan pelaksanaan prinsip PSG secara umum dari aspek process SMKN 1 Pangkalan Kerinci lebih efektif dibandingkan dengan SMKN 1 Ukui, (11) ditinjau dari sisi product, pelaksanaan PSG pada SMK Negeri 1 Pangkalan Kerinci dan SMK Negeri 1 Ukui sudah efektif, walaupun masih nampak jelas perbedaaan kualitas dari masing-masing sekolah. SMKN 1 Pangkalan Kerinci berada dibawah SMKN 1 Ukui. Untuk prestasi siswa di bidang akdemis masingmasing sekolah meningkat, kemampuan praktikum siswa juga meningkat. Tingkat kepercayaan diri siswa dalam menghadapi Ujian Nasional juga meningkat.

Saran

Adapun saran yang dapat dikemukakan antara lain: (1) bagi institusi pendidikan khususnya SMK yang ada di lingkungan kabupaten Pelalawan penelitian ini dapat menjadi gambaran pelaksanaan prinsip PSG yang telah diterapkan dengan berbagai kelebihan dan kekurangannya, sehingga dapat digunakan sebagai bahan evaluasi lebih lanjut untuk meningkatkan efektifitas pelaksanaan prinsip PSG, (2) bagi peneliti lain yang tertarik untuk mengangkat tema keefektifan pelaksanaan pendidikan sistem ganda pada sekolah menengah kejuruan disarankan untuk melakukan penelitian sejenis pada sekolah-sekolah yang berada pada lingkungan industri ataupun lingkungan non industri untuk melihat sejauh mana keefektifan pelaksanaan pendidikan sistem ganda pada sekolah tersebut.

\section{Daftar Pustaka}

Ahmadi, A. H., \& Uhbiyati, N. (2001). Ilmu pendidikan. Jakarta: Rineka Cipta.

Anonim. (2008). The educational System in Germany, The Dual System: Part-time Vocational Education, The Development and Implementationof Education Standards inGermany, Archived information 1999, 2008. (http://www.ed.Gove/pubs/Germ an Case study/chapter 2nd, html).

Anwar. (2012). Pendidikan kecakapan: Hidup konsep dan aplikasi. Bandung: Alfabeta

Ardika, N. (2011). Analisis pelaksanaan pendidikan sistem ganda (PSG) pada SMK Negeri 2 Seririt. Universitas Pendidikan Ganesha.

Arikunto, S. (2012). Manajemen pendidikan. Yogyakarta: Aditya Media.

Depdibud. (1997). Keterampilan menjelang 2020 untuk era global. Jakarta: Dit. Dikmenjur. 
(1997). Perangkat pendukung pelaksanaan pendidikan sistem ganda. Jakarta: Dit. Dikmenjur.

(1994). Konsep pendidikan sistem ganda pada SMK di Indonesia. Direktorat Jendral Pendidikan Dasar dan Menengah Departemen Pendidikan dan Kebudayaan. Jakarta: Dit. Dikmenjur.

(1992). Keputusan menteri RI nomor 490/U/1992, tentang SMK.

Djojonegoro. W. (1999). Pengembangan sumber daya manusia: Melalui Sekolah Menengah Kejuruan (SMK). Jakarta: PT. Balai Pustaka.

Hamalik, O. (2011). Perencanaan pengjararan berdasarkan pendekatan sistem. Jakarta: PT. Bumi Aksara.

(2004). Proses belajar mengajar. Jakarta: PT. Bumi Aksara.

Mulyasa, (2012). Kurikulum tingkat satuan pembelajaran. Bandung: PT. Remaja Rosdakarya Offset.

.(2004). Kurikulum berbasis kompetensi, konsep, karakteristik dan im- plementasi. Bandung: PT. Remaja Rosdakarya Offset.

Peraturan, Pemerintah RI, Nomor 29 Tahun 1990 Tentang Pendidikan Menengah.

Siregar, S. (2010). Statistika deskriptif untuk penelitian. Bandung: Rajawali Perss.

Stufflebeam, D. L \& Anthony J. S. (1986). Systematic evaluation: A self-instructional guide to theory and practice. Boston: Kluwer-Nijhoff Publishing.

Sudjana, N. (2001). Dasar-dasar proses belajar mengajar. Bandung: Sinar Baru Algessindo.

Surachim, A. (2013). Dual education system (PSG) effectiveness to improving SMK graduates quality. International Journal of Science and Research (IJSR), India Online. Volume 2, Issue 6, June.

Wena, M. (1997). Pemanfaatan industri sebagai sumber belajar dalam pendidikan sistem ganda. Jurnal pendidikan dan kebudayaan.Th. III, No. 010 September. 